\title{
Myxobolus oralis sp. n. (Myxosporea: Bivalvulida) infecting the palate in the mouth of gibel carp Carassius auratus gibelio (Cypriniformes: Cyprinidae)
}

\author{
Yang Liu ${ }^{1,2,3}$, Christopher M. Whipps ${ }^{4}$, Pin Nie ${ }^{1,5}$ and Zemao Gu ${ }^{1,2,3}$ \\ ${ }^{1}$ Department of Aquatic Animal Medicine, College of Fisheries, Huazhong Agricultural University, Wuhan, China; \\ ${ }^{2}$ Key Lab of Freshwater Animal Breeding, Ministry of Agriculture, Wuhan, China; \\ ${ }^{3}$ Freshwater Aquaculture Collaborative Innovation Center of Hubei Province, Wuhan, China; \\ ${ }^{4}$ State University of New York College of Environmental Science and Forestry, Environmental and Forest Biology, Syracuse, NY, \\ USA; \\ ${ }^{5}$ Institute of Hydrobiology, Chinese Academy of Sciences, Wuhan, China
}

\begin{abstract}
During a survey on the myxosporean fauna of gibel carp Carassius auratus gibelio (Bloch) in China, a species of Myxobolus Bütschli, 1882 that did not conform to any known species was found. The species is characterised by the presence of round to ellipsoidal plasmodia of 2.6-4.0 mm in diameter in the palate of host. Mature spores are obovate in frontal view and lemon-shaped in lateral view, with the following range, mean and standard deviation of dimensions: $10.8-12.8 \mu \mathrm{m}(11.7 \pm 0.4 \mu \mathrm{m})$ long, $8.2-9.9 \mu \mathrm{m}$ $(8.9 \pm 0.4 \mu \mathrm{m})$ wide and $6.0-7.5 \mu \mathrm{m}(6.8 \pm 0.3 \mu \mathrm{m})$ thick. Two polar capsules are pyriform, $4.0-5.5 \mu \mathrm{m}(4.8 \pm 0.3 \mu \mathrm{m})$ long by 2.9-3.6 $\mu \mathrm{m}(3.0 \pm 0.2 \mu \mathrm{m})$ wide. Polar filaments are coiled, with 5 to 6 turns. A small proportion of spores possesses a short caudal process. Scanning electron microscopy revealed discoid spores with a low sutural ridge and middle bulge. The small subunit ribosomal DNA sequence of this species did not match any available sequences in GenBank. Phylogenetically, this species is sister to M. nielii (Nie et Li, 1973) and M. hearti Chen, 1998 in a Henneguya-Myxobolus clade with robust support. Given the morphological and molecular differences between this species and other Myxobolus species, we propose the name Myxobolus oralis sp. n. for this parasite from gibel carp.
\end{abstract}

Keywords: Myxozoa, ultrastructure, SSU rRNA gene, phylogenetics, morphology

Myxobolus Bütschli, 1882 is a genus with the greatest number of described species in the Myxosporea (Lom and Dyková 2006). Some of these species have been reported as significant pathogens of cultured and wild fishes (Chen and Ma 1998, Kent et al. 2001, Lom and Dyková 2006). Specific examples include the well known Myxobolus cerebralis Hofer, 1903, which causes whirling disease of salmonids (Gilbert and Granath 2003); Myxobolus acanthogobii Hoshina, 1952 that infects the brain of Japanese amberjack Seriola quinqueradiata Temminck et Schlegel causing host scoliosis (Yokoyama et al. 2004), and Myxobolus buckei Longshaw, Frear et Feist, 2003, which infects the spinal column of cyprinid fishes (Longshaw et al. 2003).

With the increased interest taken in diseases caused by Myxobolus species and myxosporeans in general, numerous Myxobolus species have been described. In 1991, Landsberg and Lom provided the synopsis of Myxobolus species that included 444 nominal species. This expanded greatly in the following 15 years, with Erias et al. (2005) and Lom and Dyková (2006) reporting 744 and 792 nominal species, respectively. Up to the present time, approximately 850 Myxobolus species have been described (Molnár 2011). This rapid expansion of nominal species is indicative of the interest in Myxobolus species, and also what is likely a great diversity within this genus. Documenting these new species greatly increased the known diversity of myxobolids and prospectively identified species with potential pathological threats to fish.

Gibel carp Carassius auratus gibelio (Bloch), a triploid gynogenetic species with fast growth potential, is an important commercial fish species in China. It has been cultured for more than 30 years in China and annual production is estimated at more than 2 million tons (Wang et al. 2011). However, the diseases caused by Myxobolus species have been the threat to this important commercial fish and resulted in mass mortality or loss of economic value (Liu et al. 2010a, 2012, Zhang et al. 2010a,b, Xi 
et al. 2011). To generate baseline data on Myxobolus diversity in gibel carp, we conducted a survey of these parasites in China. Here, we report a novel Myxobolus species infecting the palate in the mouth of gibel carp and describe its morphological, ultrastructural and molecular characteristics.

\section{MATERIALS AND METHODS}

\section{Fish samples}

Twenty specimens of gibel carp ranging from 300-450 g in weight were purchased from Baishazhou Fish Market, Wuhan City, Hubei Province, China in November 2011. Fish were transported to the Laboratory of Fish Diseases at the Huazhong Agricultural University in China and held in aquaria, where they were euthanised with $0.2 \mathrm{mg} / \mathrm{ml}$ tricaine methanesulfonate (MS222, Sigma, St Louis, USA) prior to dissection.

\section{Morphological examinations}

Gross microscopic examinations of all organs for myxosporean infections were conducted according to Lom and Dyková (1992a) within $24 \mathrm{~h}$ after transportation. Plasmodia containing myxospores consistent with those of the genus Myxobolus were collected from the palate of gibel carp. Fresh spores from one plasmodium were measured according to Lom and Arthur (1989). Measurements of spores were performed using an Olympus $\mathrm{BH} 2$ microscope equipped with an ocular micrometre. Mean and standard deviations of each spore dimension were obtained from fresh mature spores $(n=30)$. Digitised images were obtained from the fresh wet mounts by a Nikon Eclipse 80i microscope. Line drawings were made based on the digitised images. All measurements are given in micrometres $(\mu \mathrm{m})$ unless otherwise indicated.

\section{Scanning electron microscopy}

Fresh spores were fixed in a solution of $3 \%$ glutaraldehyde at $4{ }^{\circ} \mathrm{C}$, dehydrated with $\mathrm{CO}_{2}$ using the critical point method and sputter coated with gold (Liu et al. 2014). Samples were then examined with a JSM-6390 scanning electron microscope at $20 \mathrm{kV}$ with a working distance of $18 \mathrm{~mm}$.

\section{Transmission electron microscopy}

Fresh spores were fixed in $3 \%$ glutaraldehyde at $4{ }^{\circ} \mathrm{C}$, dehydrated, infiltrated and embedded in Epon812 (Ye et al. 2012). Ultrathin-sections were observed using a HITACHI H-7650 transmission electron microscope at $75 \mathrm{kV}$.

\section{DNA isolation and sequencing}

Genomic DNA was extracted from the spores in a plasmodium fixed in $100 \%$ ethanol. The small subunit ribosomal RNA (SSU rRNA) gene was amplified following the procedure of Liu et al. (2014). The PCR products were separated using a 1.0\% agarose gel and sequenced directly with an ABI PRISM ${ }^{\circledR}$ 3730XL DNA sequencer (Applied Biosystems Inc., Foster, USA). A contiguous DNA sequence was assembled and deposited in GenBank. A nucleotide-nucleotide BLAST search was conducted to query posted sequences.

\section{Phylogenetic analysis}

To evaluate the relationship of the current species to existing myxobolids, 51 sequences were aligned with Clustal X version 1.8 (Thompson et al. 1997). The alignment consisted of the top BLAST search matches and representatives of neighbouring clades based on earlier analyses of the myxobolids (Liu et al.

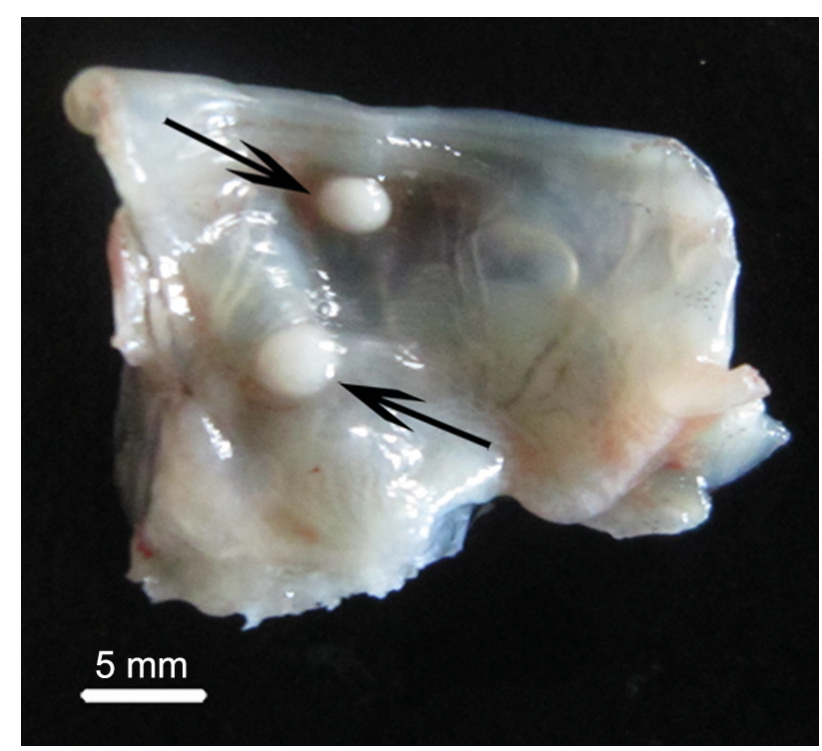

Fig. 1. Maxillary cut from the palate infected with two large plasmodia of Myxobolus oralis sp. n. from Carrasius auratus gibelio (arrows).

2010b, Liu et al. 2012). Ceratomyxa shasta Noble, 1950 served as an outgroup. Phylogenetic analyses were carried out on this 1424 character alignment following the procedure of Liu et al (2010b). A maximum likelihood (ML) analysis was conducted using the general time reversible model $(\mathrm{GTR}+\mathrm{I}+\mathrm{G})$. Nucleotide frequencies were estimated from the data $(\mathrm{A}=0.2347$, $\mathrm{C}=0.1812, \mathrm{G}=0.2910, \mathrm{~T}=0.2932$ ), six rates of nucleotide substitution were $[\mathrm{AC}]=1.2947,[\mathrm{AG}]=4.3760,[\mathrm{AT}]=1.8746$, $[\mathrm{CG}]=0.3513,[\mathrm{CT}]=6.9900,[\mathrm{GT}]=1.0000$; proportion of invariable sites $=0.3434$; gamma distribution $=0.3748$ estimated with six rate categories. Bootstrap confidence values of ML analysis were calculated with 100 replicates. Bayesian analyses were conducted using the evolutionary model as above, with $10^{6}$ generations, tree sampling every 100 generations, with a burn-in of 250 trees.

\section{RESULTS}

\section{Myxobolus oralis sp. $\mathrm{n}$.}

Figs. 1-4

Plasmodia (Fig. 1) round or ellipsoid, 2.6-4.0 mm, histozoic in palate. Myxospores (Figs. 2A, 3) obovate in frontal view and lemon-shaped in lateral view. Spores $(\mathrm{n}=30) 10.8-12.8(11.7 \pm 0.4)$ long, 8.2-9.9 (8.9 \pm 0.4$)$ wide, $6.0-7.5(6.8 \pm 0.3)$ thick. Two polar capsules pyriform, 4.0-5.5 (4.8 \pm 0.3$)$ long by 2.9-3.6 (3.0 \pm 0.2$)$ wide. Polar filaments coiled with 5-6 turns (Fig. 4A). Two to five $\mathrm{V}$-shaped sutural ridge markings present. Intercapsular appendix small. A small proportion of spores $(11 \%$, $\mathrm{n}=100$ ) with short tail or much more clearly visible tail (up to 5.2 in length) (Fig. 2B-D). Discoid spores with low sutural ridge and middle bulge, sutural line straight and distinct (Fig. 4B).

\footnotetext{
Type host: Gibel carp Carassius auratus gibelio (Bloch) (Cyprinidae).
} 

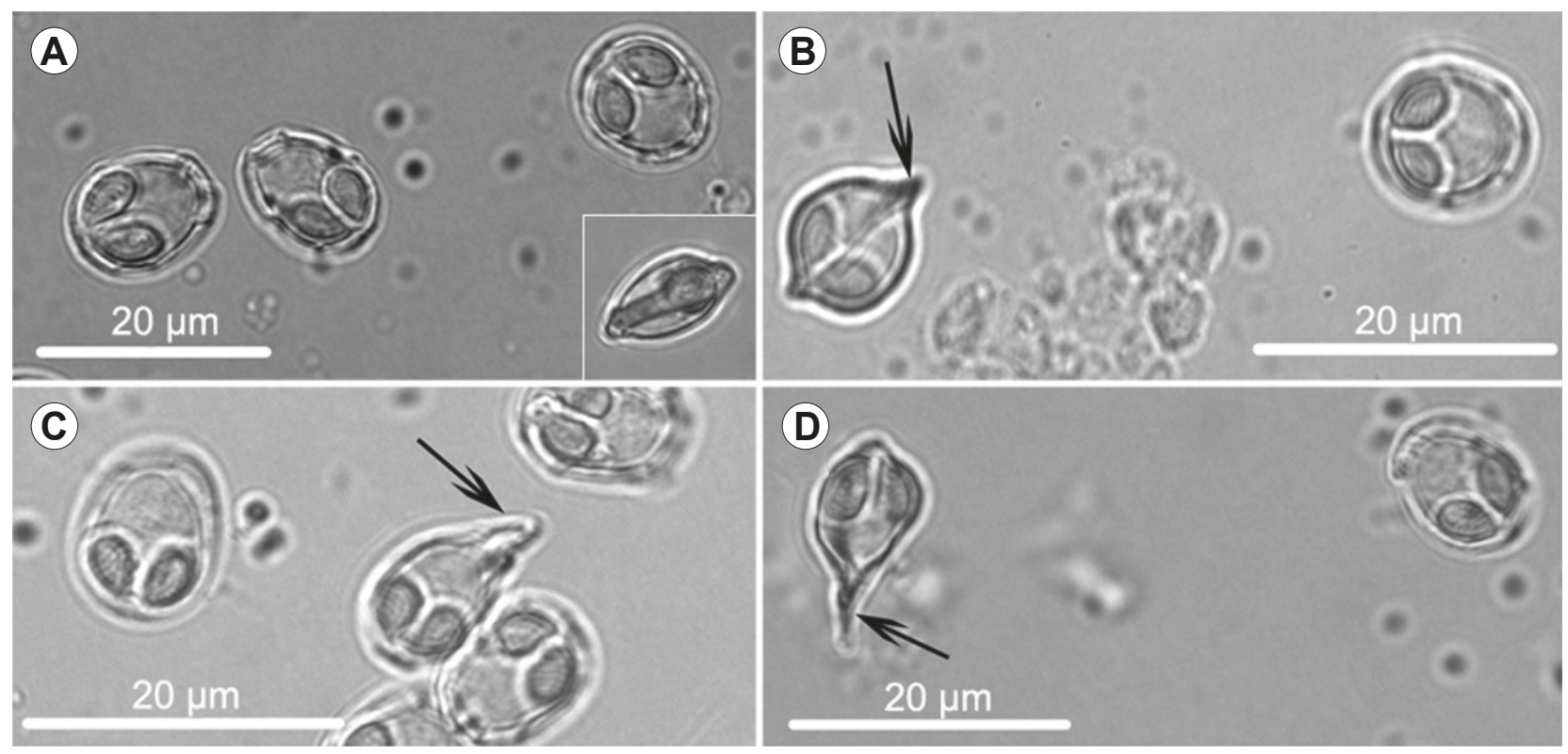

Fig. 2. Photomicrograph of fresh spores of Myxobolus oralis sp. n. from Carassius auratus gibelio. A - normal spores; inset showing spore in sutural view; B - a spore with caudal appendage (arrow); C - a spore with a short tail (arrow); D - a spore with the much elongate tail (arrow).

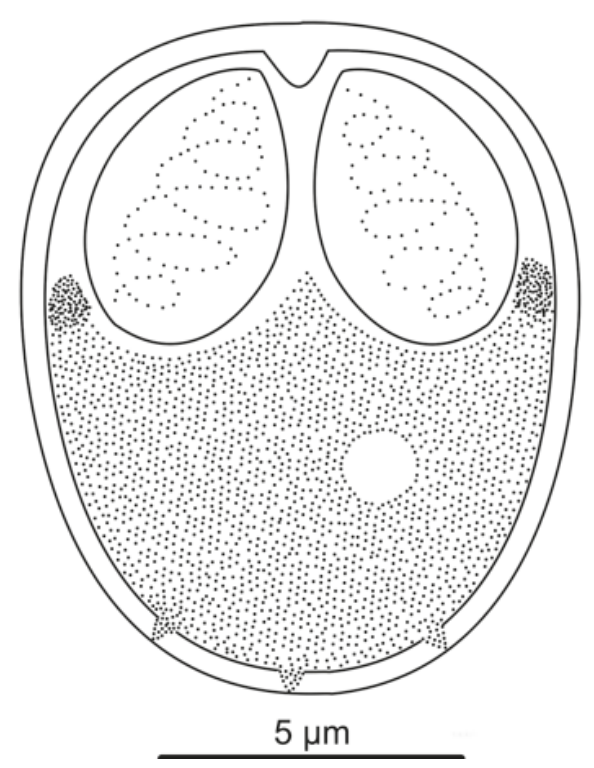

Fig. 3. Line drawing of fresh spore of Myxobolus oralis sp. n. from Carassius auratus gibelio.

Type locality: Hubei Province, China $\left(30^{\circ} 27^{\prime} 52^{\prime \prime N}\right.$, $\left.114^{\circ} 15^{\prime} 42^{\prime \prime} \mathrm{E}\right)$.

Site of infection: Palate of the mouth.

Date of sampling: November 2011.

Prevalence: $10 \%(n=20)$.

Type material: Mature spores fixed by $5 \%$ formalin deposited in Laboratory of Fish Diseases, College of Fisheries, Huazhong Agricultural University, Acc. No. MTR20111102.

E ty mology: The species is named after its site of infection.

\section{Sequence analysis}

An assembled SSU rDNA sequence of 1615 bases was deposited in GenBank (Acc. No. KC315782). A BLAST search yielded similarities to Henneguya doneci Schulman, 1962 (HM146129; 96\% over 1619 bp), Myxobolus nielii Landsberg et Lom, 1991 (JQ690358; 95\% over 1619 bp) and Myxobolus hearti Chen, 1998 (GU574808; $95 \%$ over $1613 \mathrm{bp}$ ). Phylogenetic analysis by both ML and Bayesian analysis yielded trees with similar topology, but differences in nodal support (Fig. 5). Regardless of algorithm, M. oralis sp. n. was sister to M. nielii and M. hearti. There was robust support for the HenneguyaMyxobolus clade including $H$. doneci, M. nielii, M. hearti and the new species.

\section{DISCUSSION}

More than 800 nominal Myxobolus species have been described thus far throughout the world (Lom and Dyková 2006, Molnár 2011). Given the incredible diversity coupled with the simplicity of the diagnostic stage of these species, it is often difficult to determine the validity of morphologically similar species using spore morphology alone (Molnár 2011). To avoid the above conundrum, recent studies have suggested that host and organ specificity and also tissue tropism should be taken into consideration in species identification (Molnár 1994). In addition, molecular markers are also necessary and important in identification of species of Myxobolus, especially for the species developing within identical organs and tissues of the same or closely related fishes (Eszterbauer and Székely 2004, Liu et al. 2012). Therefore, the morphology, organ specificity 

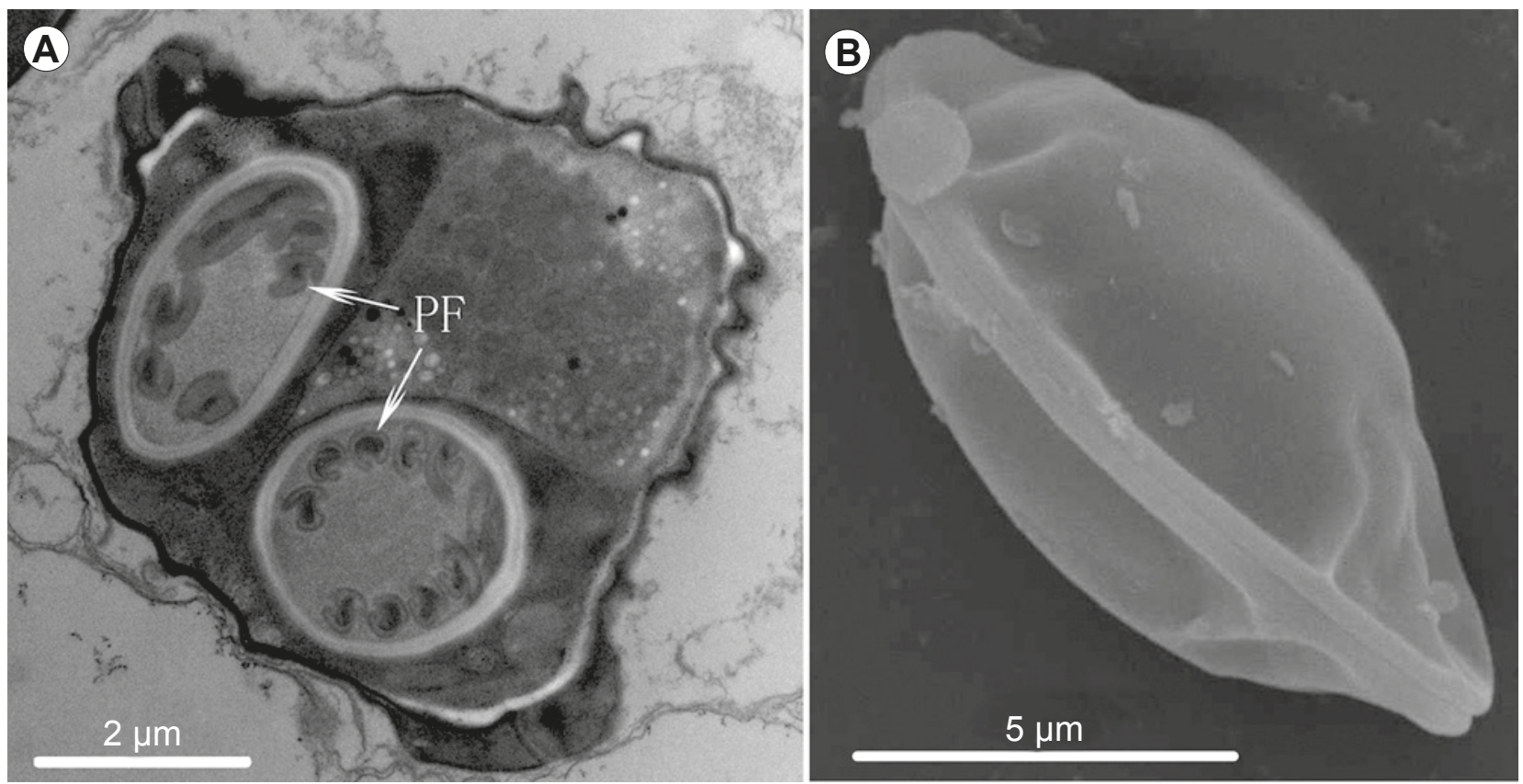

Fig. 4. Spores of Myxobolus oralis sp. n. from Carassius auratus gibelio. A - transmission electron micrograph of transverse section of a spore showing polar capsules and polar filaments (PF); B - scanning electron micrograph of the spore in sutural view with straight sutural line.

Table 1. Comparison of measurements of spores of Myxobolus oralis sp. n. with morphologically similar species. All measurements are in micrometres $(\mu \mathrm{m})$, with mean \pm standard deviation (if available), and range in parentheses.

\begin{tabular}{|c|c|c|c|c|c|c|}
\hline Parasite & M. oralis sp. $\mathrm{n}$. & $\begin{array}{l}\text { M. changkiangensis } \\
\text { Chen, } 1998\end{array}$ & $\begin{array}{c}\text { M. gibelio } \\
\text { Yukhimenko, } 1986\end{array}$ & $\begin{array}{l}\text { M. platyrostris } \\
\text { Akhmerov, } 1960\end{array}$ & $\begin{array}{c}\text { M. pyramidis } \\
\text { Chen, } 1998\end{array}$ & $\begin{array}{c}\text { M. sphaericus } \\
\text { Landsberg et Lom, } \\
1991\end{array}$ \\
\hline Source & Present study & Chen and Ma (1998) & Yukhimenko (1984) & Akhmerov (1960) & Chen and Ma (1998) & Eiras et al. $(2005)^{*}$ \\
\hline Host & C. auratus gibelio & C. auratus auratus & C. auratus gibelio & C. auratus gibelio & C. auratus auratus & C. auratus gibelio \\
\hline Infected organ & oral & gall-bladder & gills, fins, kidneys & - & gills & kidneys \\
\hline SB shape & obovate & ovate or long-ovate & obovate & angular ovate & pyriform & round \\
\hline SB length & $11.7 \pm 0.4(10.8-12.8)$ & $12.2(10.8-13.4)$ & $10.5-12.6$ & 12 & $10.2(9.6-11.0)$ & $8.5-12$ \\
\hline SB width & $8.9 \pm 0.4(8.2-9.9)$ & $8.8(8.4-9.6)$ & $7.4-10.0$ & 8 & $10.0(8.4-10.8)$ & $9-11$ \\
\hline SB thickness & $6.8 \pm 0.3(6.0-7.5)$ & $7.2(6.8-7.6)$ & 6.0 & - & 6.0 & 6 \\
\hline Polar capsule length & $4.8 \pm 0.3(4.0-5.5)$ & $6.7(6.0-7.2)$ & $3.6-5.3$ & 4 & $5.2(4.5-6.0)$ & $4.5-5.5$ \\
\hline Polar capsule width & $3.0 \pm 0.2(2.9-3.6)$ & $3.4(3.1-3.6)$ & $2.6-3.5$ & 2.8 & $3.3(3.0-3.6)$ & $2.6-3.5$ \\
\hline Intercapsular process & Small & Small & Small & Non-existent & Distinct & - \\
\hline No. filament turns & $6-7$ & $5-6$ & - & - & $5-6$ & - \\
\hline
\end{tabular}

* data from Eiras et al. (2005) synopsis, not original description; SB - spore (body).

and molecular characteristics of the present species were studied.

The morphology of the myxosporean spores described in this paper is consistent with that of Myxobolus. When compared with species of Myxobolus previously described (Chen and Ma 1998, Erias et al. 2005, Zhao et al. 2008, Zhang et al. 2010a, Liu et al. 2012), the present species is distinct. Myxobolus oralis sp. n. resembles the following species: Myxobolus pyramidis Chen, 1998; Myxobolus changkiangensis Chen, 1998; Myxobolus sphaericus (Fujita, 1924); Myxobolus platyrostris Akhmerov, 1960; and Myxobolus gibelio Yukhimenko, 1986 (Table 1).

However, M. oralis sp. n. can be distinguished as follows. Myxobolus pyramidis infects gills of gold fish rather than the palate and bears pyriform spores(vs ovoid spores in M. oralis). Myxobolus changkiangensis has a distinctly longer polar capsule than M. oralis. The morphometric data of M. sphaericus and M. platyrostris are incomplete, making accurate comparison challenging. However, they could be distinguished from $M$. oralis by the reported round and square spore shape, respectively. Despite superficial similarity of M. gibelio to M. oralis, there is a distinct pit at the anterior end of the $M$. gibelio spore, which is absent in M. oralis. In addition, these two Myxobolus species show different site of infection with $M$. gibelio infecting the gills, fins and kidneys of host.

Molecular biological methods have become essential in identification of myxosporeans (Kent et al. 2001, 


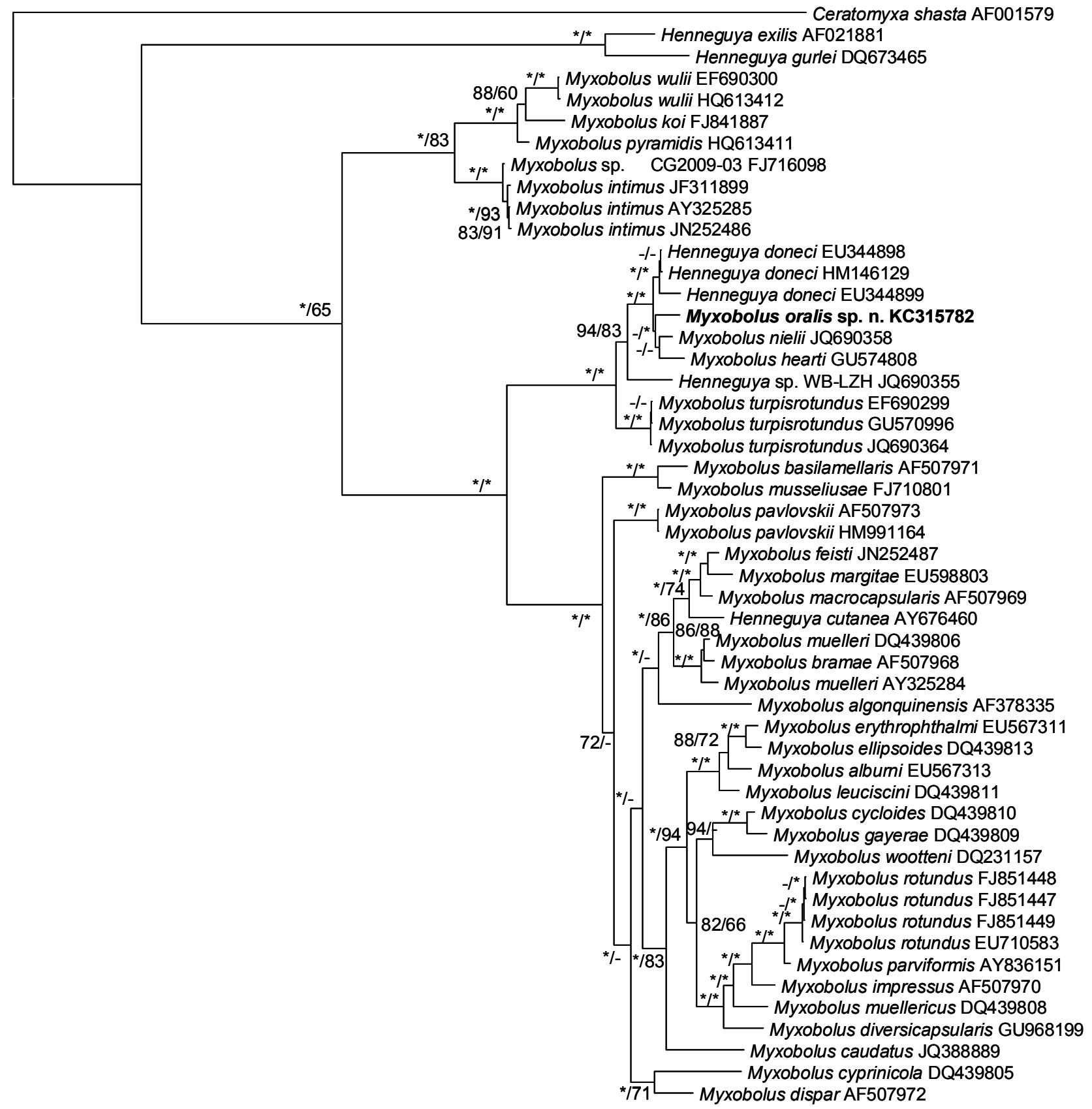

0.1

Fig. 5. Phylogenetic tree generated from Bayesian analysis of SSU rRNA gene sequences of Myxobolus oralis sp. n. from Carassius auratus gibelio and related myxobolids. GenBank accession numbers are listed adjacent to species names. Support values in percent units at branching points are listed as: Bayesian posterior probabilities/bootstrap values from ML analysis. Asterisks are shown where values exceeded $95 \%$. Dashes are shown for values under $60 \%$.

Lom and Dyková 2006, Molnár 2011), but many nominal species have not been sequenced. This is the case for $M$. changkiangensis, M. sphaericus, M. platyrostris and $M$. gibelio. DNA sequence is available for $M$. pyramidis (HQ613411), but this species was just 91\% similar to $M$. oralis. In addition, a BLAST search indicated that the DNA sequence of $M$. oralis did not match any other myxosporean sequences in GenBank, sharing 96\%, 95\%, 95\% similarity with $H$. doneci, $M$. nielii and $M$. hearti, which are generally outside the intra-specific sequence variation of what has been reported for species of myxosporeans (Whipps et al. 2004, Molnár et al. 2006, Whipps and Diggles 2006, Whipps and Kent 2006, Ferguson et al. 2008). 
The genera Henneguya Thélohan, 1892 and Myxobolus are distinguished by the presence and absence of caudal appendages (Lom and Dyková 1992b). However, phylogenetic studies based on the ribosomal DNA sequence data do not support a separation of these two genera (Kent et al. 2001, Fiala 2006, Fiala and Bartošová 2010, Liu et al. 2010b, Carriero et al. 2013). Kent et al. (2001) speculated that the caudal appendage of Henneguya spp. was not a valid feature for characterisation of the genus. Recently, some Myxobolus species have been reported with appendages similar to those of Henneguya species (ElMansy 2005, Bahri 2008, Liu et al. 2010b, 2013a), which supports the opinion of Kent et al. (2001). In the present study, we also observed $11 \%$ of the spores with caudal appendage. In addition, phylogenetic analysis showed M. oralis was placed sister to M. nielii and M. hearti in a Henneguya-Myxobolus clade with robust support. The observation of some proportion of Myxobolus spores with appendages further complicates the reliance of this single character to differentiate Henneguya from Myxobolus.

Acknowledgements. The authors thank Zhixin Wu, Yanhua Zhai, Mingjun Huang, Luo Jia (Huazhong Agricultural University, China) for collecting fish, Rui Fang and Junfa Yuan (Huazhong Agricultural University, China) for providing helpful suggestions on myxosporean species identification. This study was supported by the Nature Science Foundation of China (31172052), New Century Excellent Talents in University (NCET-12-0866), Special Fund for Agro-scientific Research in the Public Interest (201203086-14), and the Fundamental Research Funds for the Central Universities (2012YB10, 2013PY023, 2013PY059, 2013PY070).

\section{REFERENCES}

Aknmerov A.K. 1960: Myxosporidia of fishes of the Amur River Basin. Rybnoe Khoz. Vnutr. Vodoemov LatSSR 5: 239-308.

BAHRI S. 2008: Abnormal forms of Myxobolus bizerti and Myxobolus mülleri (Myxosporea: Bivalvulida) spores with caudal appendages. Bull. Eur. Assoc. Fish Pathol. 28: 252-255.

Carriero M.M., Adriano E.A., Silva M.R.M., Ceccarelli P.S., Maia A.A. 2013: Molecular phylogeny of the Myxobolus and Henneguya genera with several new South American species. PLoS ONE 8: e73713.

Chen Q.L., Ma C.L. (Eds.) 1998: Myxozoa: Myxosporea. Science Press, Beijing, 993 pp.

Eiras J.C., Molnár K., Lu Y.S. 2005: Synopsis of the species of Myxobolus Bütschli, 1882 (Myxozoa: Myxosporea: Myxobolidae). Syst. Parasitol. 61: 1-46.

El-Mansy A. 2005: Revision of Myxobolus heterosporus Baker, 1963 (syn. Myxosoma heterospora) (Myxozoa: Myxosporea) in African records. Dis. Aquat. Org. 63: 205-214.

Ferguson J.A., AtKinson S.D., Whipps C.M., Kent M.L. 2008: Molecular and morphological analysis of Myxobolus spp. of salmonid fishes with the description of Myxobolus fryeri $\mathrm{n}$. sp. J. Parasitol. 94: 1322-1334.

Fiala I. 2006: The phylogeny of Myxosporea (Myxozoa) based on small subunit ribosomal RNA gene analysis. Int. J. Parasitol. 36: $1521-1534$.

Fiala I., Bartošová P. 2010: History of myxozoan character evolution on the basis of rDNA and EF-2 data. BMC Evol. Biol. 10: 288.

Gilbert M.A., Granath W.O. 2003: Whirling disease of salmonid fish: life cycle, biology, and disease. J. Parasitol. 89:658667.

Kent M.L., Andree K.B., Bartholomew J.L., El-Matbouli M., Desser S.S., Devlin R.H., Feist S.W., Hedrick R.P., Hoffmann R.W., Khattra J., Hallett S.L., Lester R.G., Longshaw M., Palenzeula O., Siddall M.E., Xiao C. 2001: Recent advances in our knowledge of the Myxozoa. J. Eukaryot. Microbiol. 48: 395-413.

Landsberg J.H., Lom J. 1991: Taxonomy of the genus Myxobolus (Myxobolidae, Myxosporea): current listing of species and revision of synonyms. Syst. Parasitol. 18: 165-168.

LiU Y., Gu Z.M., Luo Y.L. 2010a: Some additional data to the occurrence, morphology and validity of Myxobolus turpisro- tundus Zhang, 2009 (Myxozoa: Myxosporea). Parasitol. Res. 107: 67-73.

Liu Y., Jia L., Huang M.J., Gu Z.M. 2014: Thelohanellus testudineus n. sp. (Myxosporea: Bivalvulida) infecting the skin of allogynogenetic gibel carp Carassius auratus gibelio (Bloch) in China. J. Fish Dis. 37: 535-542.

Liu Y., Whipps C.M., Gu Z.M.., Huang M.J., He C., Yang H.L., MolnáR K. 2013a: Myxobolus musseliusae (Myxozoa: Myxobolidae) from the gills of common carp Cyprinus carpio and revision of Myxobolus dispar recorded in China. Parasitol. Res. 112: 289-296.

Liu Y., Whipps C.M., Gu Z.M., Zeng L.B. 2010b: Myxobolus turpisrotundus (Myxosporea: Bivalvulida) spores with caudal appendages: investigating the validity of the genus Henneguya with morphological and molecular evidence. Parasitol. Res. 107: 699-706.

Liu Y., Whipps C.M., Gu Z.M., Zeng C., Huang M.J. 2012: Myxobolus honghuensis n. sp. (Myxosporea: Bivalvulida) parasitizing the pharynx of allogynogenetic gibel carp Carassius auratus gibelio (Bloch) from Honghu Lake, China. Parasitol. Res. 110: 1331-1336.

Lom J., ARTHUR J.R. 1989: A guideline for preparation of species descriptions in Myxosporea. J. Fish Dis. 12: 151-156.

Lom J., Dyková I. 1992a: Protozoan Parasites of Fishes. Developments in Aquaculture and Fisheries Science, Elsevier, Amsterdam, $315 \mathrm{pp}$.

Loм J., Dyкové I. 1992b: Fine structure of Triactinomyxon early stages and sporogony: myxosporean and actinosporean features compared. J. Protozool. 39: 16-27.

Loм J., Dyкоvé I. 2006: Myxozoan genera: definition and notes on taxonomy, life cycle terminology and pathogenic species. Folia Parasitol. 53: 1-36.

Longshaw M., Frear P., Feist S.W. 2003: Myxobolus buckei $\mathrm{sp.}$ n. (Myxozoa), a new pathogenic parasite from the spinal column of three cyprinid fishes from the United Kingdom. Folia Parasitol. 50: 251-262.

Molnár K., Marton S., Eszterbauer E., Székely C. 2006: Comparative morphological and molecular studies on Myxobolus spp. infecting chub from the River Danube, Hungary, and description of M. muellericus sp. n. Dis. Aquat. Organs. 73: 49-61. 
MOLNÁR K. 1994: Comments on the host, organ and tissue specificity of fish myxosporeans and on the types of their intrapiscine development. Parasitol. Hung. 27: 5-20.

MoLnÁR K. 2011: Remarks to the validity of Genbank sequences of Myxobolus spp. (Myxozoa, Myxosporidae) infecting Eurasian fishes. Acta Parasitol. 56: 263-269.

Thompson J.D., Gibson T.J., Plewniak F., Jeanmougin F., Higgins D.G. 1997: The CLUSTAL-X windows interface: flexible strategies for multiple sequence alignment aided by quality analysis tools. Nucl. Acids Res. 25: 4876-4882.

WANG G.T., YaO W.J., Wang J.G., Lu Y.S. 2001: Occurrence of thelohanellosis caused by Thelohanellus wuhanensis (Myxosporea) in juvenile allogynogenetic silver crucian carp Carassius auratus gibelio (Bloch), with an observation on the efficacy of fumagillin as a therapeutant. J. Fish Dis. 24: 57-60.

Whipps C.M., Diggles B.K. 2006: Kudoa alliaria in flesh of Argentinian hoki Macruronus magellanicus (Gadiformes; Merlucciidae). Dis. Aquat. Org. 69: 259-263.

Whipps C.M., EL-Matbouli M., Hedrick R.P., Blazer V., Kent M.L. 2004: Myxobolus cerebralis internal transcribed spacer 1 (ITS-1) sequences support recent spread of the parasite to North America and within Europe. Dis. Aquat. Org. 60: 105-108.

Whipps C.M., Kent M.L. 2006: Phylogeography of the cosmopolitan marine parasite Kudoa thyrsites (Myxozoa: Myxosporea). J. Eukaryot. Microbiol. 53: 364-474.

Xi B.W., Xie J., Zhou Q.L., Pan L.K., Ge X.P. 2011: Mass mortality of pond-reared Carassius gibelio caused by Myxobolus ampullicapsulatus in China. Dis. Aquat. Org. 93: 257-260.

Received 13 August 2013
Ye L.T., Li W.X., Wu S.G., Wang G.T. 2012: Supplementary studies on Henneguya doneci Schulman, 1962 (Myxozoa: Myxosporea) infecting the gill filaments of Carassius auratus gibelio (Bloch) in China: histologic, ultrastructural, and molecular data. Parasitol. Res. 110: 1509-1516.

Yokoyama H., Freeman M.A., Yoshinaga T., Ogawa K. 2004: Myxobolus buri, the myxosporean parasite causing scoliosis of yellowtail, is synonymous with Myxobolus acanthogobii infecting the brain of the yellowfin goby. Fish. Sci. 70: 1036-1042.

Yuknimenko S.S. 1984: New species of Myxosporidia of the genus Myxobolus (Myxosporidia: Myxobolidae) from Cyprinidae of the Amur River. Parazitologiya 20: 416-421.

Zhang J.Y., WANG J.G., Li A.H., Gong X.N. 2010a: Infection of Myxobolus turpisrotundus sp. $\mathrm{n}$. in allogynogenetic gibel carp, Carassius auratus gibelio (Bloch), with revision of Myxobolus rotundus (s. 1.) Nemeczek reported from C. auratus auratus (L.). J. Fish Dis. 33: 625-638.

Zhang J.Y., Yokoyama H., Wang J.G., Li A.H., Gong X.N., Ryu-Hasegawa A., Iwashita M., Ogawa K. 2010b: Utilization of tissue habitats by Myxobolus wulii Landsberg \& Lom, 1991 in different carp hosts and disease resistance in allogynogenetic gibel carp: redescription of $M$. wulii from China and Japan. J. Fish Dis. 33: 57-68.

Zhao Y.J., Sun C., Kent M.L., Deng J., Whipps C.M. 2008: Description of a new species of Myxobolus (Myxozoa: Myxobolidae) based on morphological and molecular data. J. Parasitol. 94: 737-742.

Accepted 24 May 2014 